\title{
HSD3B2 wt Allele
}

National Cancer Institute

\section{Source}

National Cancer Institute. HSD3B2 wt Allele. NCI Thesaurus. Code C105156.

Human HSD3B2 wild-type allele is located in the vicinity of 1p13.1 and is approximately 8 $\mathrm{kb}$ in length. This allele, which encodes 3 beta-hydroxysteroid dehydrogenase/delta 5->4isomerase type 2 protein, is involved in the oxidative conversion of ketosteroids during the biosynthesis of hormonal steroids. Mutations in this gene are associated with 3-betahydroxysteroid dehydrogenase, type II, deficiency. 